IRSTI 14.01.11

\author{
Kozhakhmetova A.K. ${ }^{1}$, Beisenbayeva L.Zh. ${ }^{2}$, \\ ${ }^{1}$ Graduate student, ${ }^{2} \mathrm{PhD}$ doctor of L.N. Gumilyov Eurasian National University, \\ Kazakhstan, Astana, e-mail: lygiara@mail.ru
}

\title{
LEAN AS A NEW INNOVATIVE METHOD IN EDUCATION SYSTEM
}

\begin{abstract}
Nowadays there are many investigations in education system, which discover and provide new methods and approaches, which help to tech and learn in effective way. In this paper we studied a new innovative method as Lean. We examine the history of this method, its effectiveness and role in education system, and tried to distinguish advantages and disadvantages of this method.
\end{abstract}

Key words: method, innovative, Lean, an effective way, academic achievement.

\author{
Кожахметова А.К.' , Бейсенбаева А.Ж.' ${ }^{2}$ \\ А.Н. Гумилев атындағы Еуразия ұлттық, университетінің \\ ${ }^{1}$ магистранты, ${ }^{2} \mathrm{PhD}$ докторы, \\ Қазақстан, Астана қ., е-mail: lygiara@mail.ru
}

Бікім беру самасында lean жаңа әдіс ретінде

Білім саласында көптеген зерттеу жұмыстары жасалып, болашағымызды құрайтын жас ұрпаққа сапалы білім беру үшін инновациялық әдістер енгізіліп жатыр. Сондықтан біз жаңашылдықпен бірге аяқ басып отыруымыз керек. Осы мақалада қазіргі таңда білім саласына жаңа әдіс ретінде енген Lean әдісі туралы сөз қозғалды. Үнемді білім беру әдісінің шығу тарихы, білім саласында қолданысы мен алатын орны, оның артықшылығы мен кемшілігі қарастырылды.

Түйін сөздер: әдіс, Lean, үнемді білім беру, тиімді жол, оқудағы жетістік.

\author{
Кожахметова А.К. ${ }^{1}$, Бейсенбаева А.Ж. ${ }^{2}$, \\ ${ }^{1}$ магистрант, ${ }^{2} \mathrm{PhD}$ доктор \\ Евразийского национального университета им. А.Н. Гумилева, \\ Казахстан, г. Астана, e-mail: lygiara@mail.ru
}

Lean как новый метод в системе образования

\begin{abstract}
В настоящее время в системе образования существует множество исследований, которые открывают и предоставляют новые методы и подходы, которые помогают эффективно обучать и учиться. В Аанной работе мы изучили новый инновационный метод - Lean. Мы изучили историю этого метода, его эффективность и роль в системе образования, а также попытались выделить преимущества и недостатки этого метода.
\end{abstract}

Кмючевые слова: метод, Lean, инновация, эффективный подход, Аостижения в учебе.

The president of our country, Nazarbayev N.A., said «If we don't be competitive in education-science sphere, we will not reach our goals. Everything begins from the school.» (http://www.akorda.kz/ en/events/akorda_news/press_conferences/coursetowards-the-future-modernization-of-kazakhstansidentity). Nowadays we involve alteration, also new requirements are set in the education system of our independent country. It means, according to the modern life teachers should be acquainted with new technology and they should be able to use innovation methods appropriately and in an effective way. Addition to this, teachers don't give learners ready education, ready material, they create an environ- 
ment where they teach how to learn, how to search, and think about thinking. That's why teachers should analyse the process of teaching, organizing of the lesson and the material which want to give.

The Lean method which has mentioned in this paper is the new one. Actually, the history of Lean is connoted with the Toyota, which is car producer company. It began its work in 1937. The manager of this center, Taiichi Ohno, found the method Lean. The main objective of this method was to take care of the issue of waste, for instant, decreasing time and amplifying an incentive by disposing of and engaging representatives. The purpose of lean is to stand development by adjusting consumer loyalty to representative fulfillment. It additionally looks to offer innovative items and administrations gainfully while limiting useless over-expenses to clients, providers, and nature. The essential knowledge of lean intuition is that if each representative is prepared to distinguish dawdled and exertion in their own occupation, they can cooperate all more successfully to enhance forms by taking out such waste. Lean's approach is to participate with the client; it concentrates on clients' needs as an ultimate objective (Ziskovsky, B., \& Ziskovsky, J., 2007).

On the other word, Lean is a method that is used to improve the quality of the product. Lean is required for creating a strong environment for the business. The strength of the lean methods has disapproved all other methods. Regular evaluation of the business has allowed other business sectors.

Lean methods are an economical way of reducing the waste in business. The lean methodology aims at reducing the waste production simply by reducing the unnecessary processes that might be contributing to the waste production and does not have effects on the quality of the product (Womack, J. P., and Jones, D. T., 1996: 144-145). But we know that it is using in the education system, not just in business sphere. So, in this paper we tried to find out the way how it can be involved in the teaching process.

If we look at this approach from the educational point, the Lean method includes the states of affairs which help to avoid waste and add value to the process that it serves. Lean is an organizational development program, which main objectives are to improve individual performance and job satisfaction of people in the education system. Here students take responsibility for their learning process and future success. It means they can choose the discipline, they can choose the curriculum and choose the forms of teaching and learning. Also, they can discuss and solve the problem together which appears during the learning process.
As a waste removing approach, Lean has begun to demonstrate its effectiveness in the developmental processes of education as well as innovations it has made in other industrial field development processes. The field of education is very new in this context and Lean practices has shown that it can create value-added by keeping the awareness at a high level, reducing school costs, reducing preparation time, recovering waste, and allowing processes to proceed in a planned manner (Womack, J. P., and Jones, D.T., 1996: 144-145).

Continuous improvement is a key used at all stages of Lean. The process including all these, a complete curriculum and complete learning at low cost will create a chain of success starting from a single student and reaching the whole society. Lean education requires every individual who takes part in the cycle of educational institutions to find innovative solutions to problems, dynamics of learning and teaching activities, and to work together. Using Lean tools to increase productivity in educational institutions will enable educators to put Lean education culture into practice. (Cleary, B. A., \& Duncan, S. J., 2008 1996: 167)

The biggest hurdle facing Lean's educational adaptation is the negative habits in education. In other words: refraining from progress and innovation. Education is a system that covers all the processes involved in the distribution of knowledge. All of these processes may be improved by examining the management, teaching, and learning processes in our educational institutions. Sustainable success may be achieved by effective use of workforce including teamwork. Thus, we can make school management, teachers, students and families most efficient. (Scott, S. T., 2008: 5-6)

Lean in education system helps to improve the job satisfaction of each individual in the school system and advances from school management to parents and from student to teachers. And it involves everyone in arranging their own learning process and the identification and purification of unnecessary, ineffective things that are found in each process. So, if we want to apply this method in the education system, we should remember some components.

The first component to be understood in order to put Lean education into practice in schools is Lean thinking. Lean thinking is a thinking system that is based on the effective use of all necessary educational components and elimination of all the components that are not necessary in education, in other words, which create waste in the processes. Through Lean thinking, teachers and students will easily identify the requirements for top-level learning and 
use Lean thinking in an effective way to catch up with the curriculum without losing time to reach that goal. (George, M. L., \& George, M., 2003: 273)

The second component in Lean's educational adaptation is Lean culture. Lean culture is a continent that has always been dedicated to development, encouraging and empowering everyone to be a problem-solver, enabling recognition of success, and not misleading others because of failure. Lean culture is based on respect for people because of the work they do and the essential contribution each individual makes to the institution. (Flinchbaugh, J., and Carlino, A., 2006: 115)

The next Lean education component is load balancing, and load balancing is one of the key points in adaptation of Lean into education. Load balancing is a term used to balance the curriculum in the field of education, and it is a calculation of how much time should be devoted to the topic to be taught. Load balancing has two basic building blocks, the first is to determine what needs to be accomplished, and the second is to decide which tasks should be done in how much time. (Maguad, B. M., 2011)

The most basic points among these stages are those related to the mission, because Lean thinking system aims to increase the degree of harmony between action and mission. The class mission is describing the purpose of existing in the class through the description of the work itself. It is the explanation of why the teacher and the student should work together in this job as well as the personal acquirement of doing it. (Stecher, B. M., Kirby, S. N., Barney, H., Pearson, M. L., \& Chow, M., 2004:49)

In addition, according to the Ziskovsky J. \& Ziskovsky B., they mentioned that the main part is the time where we can make up for the curriculum in different cases. So, they thought that if we hadn't time for compensation, it would be dangerous and then we couldn't follow the plan and curriculum which we created. Teachers can create a new solution by starting from the tail and working backwards to gain a new perspective while creating their own load balancing plans, and they can also develop dif- ferent perspectives by coming to the head from the tail.

How we said Lean is about removing wastes that appear in learning process. If schools want to apply it, they should evaluate any wasted space that may be involved in the education process. They should mark the following points which influence to the work. They should pay attention to the creating an environment, avoiding of unnecessary materials, the cleanness of work place, and think and prevent the problems which can appear and interrupt the learning process.

One of the first countries which apply Lean method is Albania. Here they made a research. The participants were students and teachers. Fiftyfour teachers were surveyed, they had more than five-year experiences and they worked in different schools of the world. They mentioned eight wastes which could be in learning process. We will mark some major of them. The first one is explaining the new theme and its repetition again and again in forty minutes. The second is doing exercises which are not effective and unnecessary. And the last one is capabilities. Here we can say there aren't qualified staff, which are not motivated. As a result of this research, to enter the method Lean we should create Lean culture, provide an environment, where students and teachers can work together.

In summary, the main purpose of Lean education is to try to realize the philosophy of personal or planned development, which is expressed as a dedication to a continuous development, that is, a situation that will never end in order to do the best, by removing the waste from all the processes of education. When Lean education method is put into practice in schools to the full, the curriculum will be able to improve, the course success and the school achievement average in the standardized exams will increase as a result of the waste prevention principle of Lean method. It offers a great contribution to education system via standardization of the institution. This innovative model may also help the operation a staff has more time to do other tasks.

\section{Литература}

Cleary B. A., Duncan, S. J. Thinking tools for kids: An activity book for classroom learning. - ASQ Quality Press, 2008. - P.167. Çalişkan Nilüfer; Mulgeci. Akida Waste Identification Lean Approach in effective education system Case of Albania, 2015.

Dahlgaard J. J., Østergaard P. TQM and lean thinking in higher education. The Best on Quality: Targets, Improvements, Systems, 11, 2000. - P. 203-226.

Flinchbaugh J., Carlino A. The Hitchhiker's Guide to Lean: Lessons from the Road. - Dearborn, MI: Society of Manufacturing Engineers, 2006. - P. 115.

George M. L., George M. Lean six sigma for service. - New York, NY: McGraw-Hill, 2003. - P. 273.

Maguad B. M. Lean strategies for education: overcoming the waste factor. - 2011. 
Назарбаев Н.Ә. Болашаққа бағдар: рухани жаңғыру. - Астана, 2017. Retrieved from http://www.akorda.kz/en/events/akorda_news/press_conferences/course-towards-the-future-modernization-of-kazakhstans-identity

Scott S. T. An argument for redefining public schools. In S. Flumerfelt (Ed.), White papers. The Pawley Institute for Learning, 2008. - P. 5-6.

Stecher B. M., Kirby S. N., Barney H., Pearson M. L., Chow, M. Organizational improvement and accountability: Lessons for education from other sectors. - Rand Corporation, 2004. - P. 49.

Womack J. P., Jones D. T. Beyond Toyota: How to root out waste and pursue perfection. - Harvard Business Review, 74(5), 1996. - P. 140-158.

Ziskovsky B., \& Ziskovsky J. Doing more with less - Going lean in education. Lean education enterprises. - Shoreview/Minnesota, 2007.

Ziskovsky B., \& Ziskovsky J. Optimizing Student Learning: A Lean Systems Approach to Improving K-12 Education. -ASQ Quality Press, 2010.

\section{References}

Cleary B. A., Duncan S. J. (2008) Thinking tools for kids: An activity book for classroom learning. ASQ Quality Press, 2008. p.167. (in English)

Çalişkan Nilüfer; Mulgeci Akida (2015) Waste Identification Lean Approach in effective education system Case of Albania, 2015. (in English)

Dahlgaard J. J., Østergaard P. (2000) TQM and lean thinking in higher education. The Best on Quality: Targets, Improvements, Systems, 11, 2000. p. 203-226. (in English)

Flinchbaugh J., Carlino A. (2006) The Hitchhiker's Guide to Lean: Lessons from the Road. Dearborn, MI: Society of Manufacturing Engineers, 2006. p.115. (in English)

George M. L., George M. (2003) Lean six sigma for service. New York, NY: McGraw-Hill, 2003. p.273. (in English)

Maguad B. M. (2011) Lean strategies for education: overcoming the waste factor. 2011. (in English)

Nazarbayev N.A. Bolashakka bagdar - rukhany zhangyru [Course towards the future: modernization of Kazakhstan's identity]. Astana, 2017. Retrieved from http://www.akorda.kz/en/events/akorda_news/press_conferences/course-towards-the-future-modernization-of-kazakhstans-identity (in Kazakh)

Scott S. T. (2008) An argument for redefining public schools. In S. Flumerfelt (Ed.), White papers. The Pawley Institute for Learning, 2008. p. 5-6. (in English)

Stecher B. M., Kirby S. N., Barney H., Pearson M. L., Chow M. (2004) Organizational improvement and accountability: Lessons for education from other sectors. Rand Corporation, 2004. p. 49. (in English)

Womack J. P., Jones D. T. (1996) Beyond Toyota: How to root out waste and pursue perfection. - Harvard Business Review, 74(5), 1996. p. 140-158. (in English)

Ziskovsky B., \& Ziskovsky J. (2007) Doing more with less - Going lean in education. Lean education enterprises. Shoreview/ Minnesota, 2007. (in English)

Ziskovsky B., \& Ziskovsky J. (2010) Optimizing Student Learning: A Lean Systems Approach to Improving K-12 Education. ASQ Quality Press, 2010. (in English) 